\title{
The Effectiveness of Corporate Governance in Uganda: The Case of Private Companies
}

\author{
David Lwanga ${ }^{1}$, Doreen Basemera ${ }^{2}$ \\ ${ }^{1}$ Mountains of the Moon University \\ Uganda \\ Email: amootido [AT] gmail.com \\ ${ }^{2}$ Mountains of the Moon University \\ Uganda \\ Email: vividlwanga [AT] gmail.com
}

\begin{abstract}
This paper examines the effectiveness of rules, procedures and Acts as instruments of corporate governance in Uganda, with interest in the performance of private companies. An extensive review of literature and ethnographic observation of the dynamic of corporate governance in private companies indicate that much as the private companies have adopted a hybrid regulatory framework of corporate governance, loopholes do still exist that have hindered the effectiveness of these instrument in the performance of private companies. Therefore there is need for strengthening corporate governance systems; however some of the weakness are attributed to the unsolved debate on key issues of corporate governance globally that trickles down to Uganda's young corporate governance system in the private sector.
\end{abstract}

Keywords---Effectiveness, Corporate Governance, Performance and Private Companies

\section{INTRODUCTION}

Issues of corporate governance are not new in governance of corporation except the concept. Concerns of corporate governance were first noticed in 1600 in the British East India company that lead this company to be nationalized ${ }^{1}$, in 1776 Adam Smith in his book Wealth of Nations did not use or invented the concept of corporate governance but recognized the dangers of separation of ownership and control in the management of capital when he stated that:

\begin{abstract}
"Owners of capital should be directly involved in management .........directors being managers of other people's money cannot be expected to watch over it with the same vigilance as owners .... negligence and profusion will prevail". Adam Smith 1776.
\end{abstract}

However the concept has come into the limelight in the late 1980s and early 1990s where a number of corporation scandals associate to corporate governance such as Enron, Polly peck International, World Com, the Bank of Commerce and Credit International lead to the collapse of International companies ${ }^{2}$, out of these scandals the UK government setup the Cadbury committee that resulted into the Cadbury report of 1992 which later become a cornerstone for corporate governance worldwide as it sprung up other institutions framework for corporate governance, ${ }^{3} .{ }^{4}$ further notes that in Africa the King report (s) of 1994 and subsequent reviews of the same report by the Institute of Directors of South Africa in response to the development of South Africa's stock market is recognized as a the initial key initiative in the development of corporate governance in Africa. According to ${ }^{5}$, corporate governance in Africa is designed to pursue eight characteristics that are discipline, transparency, independence, fairness, responsibility, accountability, ethical conduct and good corporate citizenship which are all geared towards better performance of companies thus economic development and where these

\footnotetext{
${ }^{1}$ Wanyama, S. (2014). Corporate Governance in Uganda: An Introduction to Concepts and Principles. Kampala: Fountain Publishers.

${ }^{2}$ Quéré, C. R. The Role of the State in Corporate Governance. Accounting History, Vol. 19(3) 291.(2010)

${ }^{3}$ Subramanian1, S. A Comparison of Corporate Governance Practices in State-owned Enterprises and Their Private Sector Peers in India. IIM Kozhikode Society \& Management Review , 5(2) 200-216. (2016)

${ }^{4}$ Ibidl

${ }^{5}$ Ibid, 1
} 
goals are in suspense foreign investors will hesitate to invest African countries. In Uganda specifically before the development of Uganda's capital market authority corporate governance guidelines and other regulatory framework, private companies were and are still governed by the company Act 2011, ${ }^{6}$. In Uganda and other African countries corporate governance is still in its infancy, ${ }^{7}$, as ${ }^{8}$ claims that the economic, societal, cultural environment of the country determine the path of development of corporate governance system, analysis of these factors in Uganda's context truly explain the slow development of corporate governance system in Uganda though other factors like political factors, attitude towards chances and risk, disclosure and transparency are vital, ${ }^{9}$.

The development of corporate governance framework globally and in Uganda particularly is built on three pillars that's the principles of good governance represented by transparency, accountability, openness, fairness and good citizenship, corporate governance, it is also built on corporate governance best practices which is also known as the voluntary regulatory instruments such as codes, and the last building block for corporate governance is the mandatory instruments which are rules enshrined in Uganda's laws such as the company Act. All these were intended to ensure smooth running of private companies to contribute to effectiveness of corporate governance in terms of risk management practices, the performance of the board, exercise of shareholder rights, remunerations /incentive systems, ${ }^{10}$. However despite the fact that Uganda's public and private companies have adopted the three pillars of corporate governance i.e. principles, codes and Acts to ensure effectiveness of the performance of corporate governance, the country has continued to witness massive scandals resulting from failure of corporate governance that has resulted into loss of capital investment and trust, corruption and embezzlement of funds, sale of company property without the consent of shareholders, declaim in economic growth and development, ethical and social scandals. Recent cases include a court case of Uganda Pentecostal University, where the board turned against the founders over ownership of the University, the wrangles and court cases of Uganda Muslim Supreme Council in which trustees turned against the Muslim fraternity over property management, collapse of the Crane Bank, closer of giant supermarkets Nakumatt and Uchumi in Kampala etc. These and other scandals have created a gap in the effectiveness of corporate governance in Uganda particularly in the performance of private companies. Therefore there is a need to critically examine the effectiveness of rules, procedures codes and Acts in the performance of private companies, ${ }^{11}$ notes that corporate governance a strong impact on microeconomic efficiency, function and development of capital market, resource allocation, capital mobility and globalization. So the objective of this paper is exploring the corporate governance regulatory framework in Uganda and how effective are the corporate governance instruments in the performance of private companies. The rest of the paper is structured as follows: methodology, literature and theoretical framework, result and discussion and lastly the conclusion and recommendation.

\section{METHODOLOGY}

The methodology adopted in this paper is a documentary analysis/research that involves systematic analysis of information in form of documents /data ${ }^{12}$. Several journal articles, text books, reports, and magazines have been published on corporate governance. Documentary review is a reliable approach to social science research ${ }^{13}$. Search engine like goggle scholar, and other website have been used to access these source and supplemented by data from ethnographic observation on the performance of corporate governance in Uganda in relation to rules, procedures and Acts. Through content analysis partners, themes have been developed to draw conclusion and recommendation on the effectiveness of rule, procedures and Acts on the performance of corporate governance in Uganda.

\section{LITERATURE AND THEORETICAL FRAMEWORK}

Corporate governance as a subject is still new in Uganda and in Africa, though there is no general definition for corporate governance; it has been defined differently by various scholars for instance, corporate governance is the system through

\footnotetext{
${ }^{6}$ Governmet of Uganda. The Constitution of The Republic of Uganda. Kampala, (1995).

${ }^{7}$ Hopt, A. M. Comperative Corperate Governance: A Functional and International Alysisi. United Kingdom: Cambridge University Press, (2013).

${ }^{8}$ Ibid,7

${ }^{9}$ Ibid, 1

${ }^{10}$ Ibid, 1

${ }^{11}$ Mallin, C. Corporate Governance fourth edition. United Kingdom: Oxford University Press, (2013).

${ }^{12}$ Quinlan,C., Babin, B., Carr, J., Grifin, M., \& Zkmund, W. G. Business Research Methods . Hampshire: Cengage,92015)

${ }^{13}$ Amin, M. E. Foundation of Statistical Inference for Social Science Research. Kampala: Makarere University

Printerly, (2004).
} 
which companies are directed and controlled ${ }^{14}$, Corporate governance entails a set of relationship between a company's management, its board its shareholder and other and it provides the framework through which the company objectives are set, means of achieving them and monitoring performance ${ }^{15}$. According to, ${ }^{16}$ corporate governance is viewed as the process and structures applied to direct and manage company affairs to enhance prosperity accounting with the prime aim of protecting and promoting shareholder's rights and shareholders long term value while taking into consideration the interests of all other stakeholders. Generally out of these and for the purpose of understanding this subject a simply definition provided by the Cadbury report of 1992 is picked that views corporate governance as the system by which companies are directed and controlled by the board on behalf of shareholders, ${ }^{17}$. According to ${ }^{18}$ mostly corporate governance focuses on internal balance of power within the corporation and the issue surrounding corporate governance took central stage in the aftermath of the recent financial scandals in the UK, the US and within the OECD countries. The Cadbury report of 1992 gave rise to a number of principles and procedures for corporate governance. Key actors in the corporate governance is the board considered as the agent as in the agency theory that is regulated in the corporate laws of virtually all countries, ${ }^{19}$ the shareholders or the principal.

Various theories have been postulated to account for varying approach to corporate governance for instance the transaction theory, stakeholder's theory and the agency theory among others, ${ }^{20}$. But the Agency theory, developed by Jansen $\&$ Mecckling, 1976, ${ }^{21}$ have gained prominence in explaining, predicting and describe and evaluating the relationship between the shareholders and the board. The theory which is built on the assumption of separation of ownership and control illustrates that the owners/shareholders (principal) entrust the managers /board (agent) with the company administration hoping that they will work in their interest, ${ }^{22}$ However in most cases the agents have worked contrary to the wishes of the shareholders which resulted into the development of control measures of the agents in form of corporate governance principles, codes, rules and Acts. So the development of corporate governance is an attempt to confront the conflict of interest or potential conflict of interest between shareholder, members of the board a whole or individual members and stakeholders.

\section{RESULT AND DISCUSSION}

\section{Uganda's Corporate Governance Regulatory Framework}

Critically examining the effect of corporate governance in Uganda's private companies requires a critical analysis of the level of administration, enforcement and compliance to the regulatory frame work by these companies however this will greatly differ from countries where there is well developed structure of corporate governance than to countries like Uganda where the systems are just evolving. The regulatory framework of corporate governance in Uganda is reflected in both the Mandatory and Voluntary instruments set by the government and other regulatory authorities concerning with the administration of public and private companies ${ }^{23}$. The mandatory instruments comes in forms of rules procedures Act of Laws that are enshrined in Uganda's Laws and are legally enforced, they also attract penalties for noncompliance, however according to $^{24}$, the voluntary instruments are in form of codes and guidelines that are embedded in the best practices on

\footnotetext{
${ }^{14}$ Ibid, 11

${ }^{15}$ Bratanovic, H. v. Analyzing Banking Risk A Framework for Assessing Corporate Governance and Risk Management. Washington. DC: World Bank, (2009)
}

${ }^{16}$ Authority, C. M. The Capaital Market Corporate Governace Guidlines. Kampala, (2003)

${ }^{17}$ Okoye, N. V. Behavioural Risks in Corporate Governance: Regulatory Intervention as a Risk Management Mechanism. New York: Routledge, (2015).

${ }^{18}$ Ibid, 7

${ }^{19}$ Marnet Oliver. Behaviors and Rationality in Corporate Governance. New York: Routledge,(2008).

${ }^{20}$ Ansari, S. P. A Theoretical Framework for Corporate Governance. Indian Journal of Corporate Governance , Vol,7, N0.1, (2014)

${ }^{21}$ Crowther, G. A. A Handbook of Corporate Governance and Social Responsibility. England: Gower Publishing Limited,(2010).

22 Eisenberg, P. Case Study Analysis of Corporate Governance and Management Control at Kendallville Bank. International Journal of Applied Economic Studies, Vol. 4, Issue 3, (2016).

${ }^{23}$ Ibid, 1

${ }^{24}$ Ibid, 1 
corporate governance covering issues like treatment of shareholders, conduct of the board meetings, accountability transparency, etc. Which is also known as comply -or-explain regime and the former is comply -or-else regime.

Critically examining the nature of corporate governance system for private companies in Uganda it is evidenced that they adopt what may be termed as a hybrid regulatory framework which involves both mandatory and voluntary instruments with the view that one supplements the other to minimize the weakness of each. The mandatory instrument of corporate governance in Uganda include the company Act 2012, Financial Institution Act 2004, Micro Finance and Deposit taking institution Act $2002,{ }^{25}$. The instruments specify basic corporate governance requirement that are mandatory such as to have board of directors, to file annual returns, to hold annual general meeting, to have audited accounts, allow inspection of books of accounts by shareholders. On the other hand the voluntary instruments include Institute of corporate governance of Uganda corporate governance guidelines 2008, Capital Market Authority corporate governance guidelines 2008, and the corporate governance Codes stipulated within the Company Act 2012. The legal framework in most countries were targeting corporate and stock exchange ${ }^{26}$ for the case of Uganda this sector has witnessed slow development the legal framework that governs private companies in Uganda stems from the 1995 Constitution, ${ }^{27}$. The codes of corporate governance though they are not Laws and lack binding forces companies have to follow them as they also stem firm most of prominent authentic sources such as the Cadbury report of 1992, stock exchange organizations, and supervisory agencies as for the case of Uganda they come from the supreme Law that's constitution. However in general corporate governance codes primary regulate the boards and its committees or regulate boards and committees in case of two tier system, ${ }^{28}$, there are also rules on top of codes developed to speculate on shareholder rights and audit practices.

\title{
The Effectiveness of the Instruments Corporate Governance
}

The codes requires a mild form of disclosure here a mandatory corporate governance statement must be presented to indicate whether the company is subject to corporate governance codes and if so which one most companies in Uganda have complied to these codes but also giving financial and ownership information. Institutions like Uganda investment authority, Uganda stock exchange are mandated to issue, administer, and enforce the codes, rules these institutions whose authority is backed by the Laws like the company Act, have ensured that most private companies have implemented the comply or disclosure or comply or explain requirements and this a has attracted penalties where companies are not compliant as courts attach legal consequences to false or omitted disclosure this implies that codes rule and procedure are effective in governance of private companies. To ensure compliance and adherence to rules, procedures and Acts, elements of corporate governance have become a "must have" embedded in all documents governing private companies specifying on key issues of corporate governance. For instance the Financial Institution Act 2004 that governs financial institution in Uganda part VII section 57 specifies on removal and suspension of directors, section 53 empowers the central bank to remove the direct or suspends the whole board, section 74 empowers the centre to bank reject the audit report on grounds of quality and standards all this are intended to ensure effectiveness of corporate governance in the performance of private companies

However despite the strong foundation provided by these codes to Uganda's private firms some weakness does exist in some areas of corporate governance due to weakness corporate structures, ${ }^{29}$ which has given away to abuse of trust and unethical behaviors for instance. Rights, duties and liabilities of directors have traditionally dominated the acts rules and code of private company's management but because of the weak institution enforcement and supervision directors have violated these rules which have resulted into scandals of corporate governance case of UIA, NSSF for public companies and collapse of Crane Bank. Risk management and early dictation of difficulties, because corporate Laws traditionally don't spell out in detail what management can do in cases of risk management and internal controls systems, this creates vacuum and the ineffectiveness of these codes since risk management is a business administration domain this leaves the shareholder at risk of the choice of the board. The composition and the independence of the boards of these private companies still poses a threat to various stakeholders such as investors who may wish to invest in these companies despite the existence of Laws, codes. According to EU independence is seen as being free of any business, family or other relations with the company it control shareholder or management that creates conflict of interest hence impair judgment of the board which seem to be a challenge given the historical foundation of these companies ${ }^{30}$. Where this is achieved the members

\author{
${ }^{25}$ Ibid, 1 \\ ${ }^{26}$ Ibid, 7 \\ ${ }^{27}$ Ibid, 1 \\ ${ }^{28}$ Ibid, 7 \\ ${ }^{29}$ Matthias Nnadi, U. E. Audit Quality, Family Business and Corporate Governance Mechanisms: The Case of Morocco. \\ Journal of Accounting in Emerging Economies, Vol. 7 Issue: 4,(2017).
}

${ }^{30} \mathrm{Ibid}, 7$ 
lack the competencies to fit the functions of various committees and determination of independence is still a challenge, ${ }^{31}$ to the effectiveness of corporate governance in Uganda. Remuneration, stock option and other incentives, because the laws and other the remuneration committees do not specify the packages to the board members have created loophole in the effectiveness of these codes, rule and procedures for instance boards are paid massively without commensurate performance as they is no yard stick for uniform measure of board the rule on remuneration /compensation in Uganda state that the compensation to be adequate even though the rule on disclosure require revealing the remuneration of the whole board or perhaps the five top earning directors has little to stop the board to compensate themselves exorbitantly. One of the elements of corporate governance is Corporate Social Responsibility (CSR) that requires companies to behave socially responsible for the environment and ethical, but because this is a voluntary best practice so in situations where companies do not know or ignore their CSR or if they do not behave socially responsibly then it means enforcement and compliance is limited hence CSR implementation cannot be controlled through mandatory instruments. One of the requirement or the indicator of good governance of corporate governance is to ensure control environment in which risk management framework is established to identify, assess and mitigation of risk is done, this requirement as remained on paper and where it is enforced companies lack the competencies to develop a comprehensive risk management framework and also due to the week structures various stakeholders have manipulated the framework for personal interests hence corporate scandals, for instance the collapse of Crane Bank, Nakumatt and Uchumi supermarket, recent scandals of Uganda investment authority. The supervision system within most private companies that are intended to ensure compliance with the corporate best practices is inadequate. Most of the cods and rules that are developed to protect investors are based on comply -or- explain approach where companies are supposed to comply with the provisions of the codes or explain to the shareholders why they have not complied ${ }^{32}$. This requirement is prone to violation due to the weakness in the in the determination of the validity of the explanation and inadequate system of supervision by the enforcement authorities. Addressing the weakness in supervision mechanisms lead to the development mandatory rule based approach like the one provided by the Sarbanes Oxley Act 2002 in US which was intended to seal off the weakness that was noticed in the comply-or-explain or the so called principal based approach, ${ }^{33}$ or the apply and explain approach which appreciate how the principals and recommendations have been applied hence showing progression in application of good corporate governance. Appointment of board members: one of the procedures of corporate governance is transparency in appointment of board members by the appointment committee. ${ }^{34}$, asserts that committee is charged with identifying and nominating of board candidates which process should follow a formal, rigorous and transparent procedures and it should occur at regular intervals. But considering what happens in Uganda where boards have exceeded their mandated term of office and their appointment process is not transparent, a recent case in the appoint of the CEO of Uganda Airlines, UIA, though it is a public case but it illuminate what is happening in the country.

Even though there are issues of weakness in corporate governance in Uganda's private companies which could be attributed to factors such as weak enforcement mechanism, it is observed that some of these weakness are a result of controversies surrounding unsolved issues on best practices of code of corporate governance globally and among the key issues posing a threat to corporate governance in developing countries are: The question of whether corporate governance practices be based on rules or principles, for instance companies in the US are required to abide to rules of corporate governance enshrined in SEC and stock exchange's regulations and also in laws under SOX Act, unlike on the other hand companies in the UK, Common Wealth Countries, and OECD countries are expected to follow principles of their countries codes, ${ }^{35}$. Private companies in Uganda and other developing countries have a challenge as to these two sides of governance since each side have proponents and influence the flow of investments by foreign companies. It's observed that because of this unsolved controversy Uganda decided to adopt a hybrid of corporate governance regulatory framework that utilizes rules and principles at once. The second question pertains whether the position of chairman board and CEO be occupied by different people to ensure checks and balance a case of the UK or a single leader is appropriate and as for the case of the US, observations indicates that adopting either a single person in countries like Uganda where the checks and balance are inadequate and also taking a separate method where competent and independent persons are rarely is still a source of weakness in corporate governance. Relate to this is also the question of where a retiring CEO should become the chairman board. Other areas of unsolved debate on corporate governance as elaborated by ${ }^{36}$, include whether outside independent

\footnotetext{
${ }^{31}$ Hudson, K. K. Non-Executive Directors and the Higgs Consultation paper, 'Review of the Role and Effectiveness of Non-Executive Directors'. Journal of Financial Regulation and Compliance, Vol. 10 Issue: 4, pp.361-371,(2002)

${ }^{32}$ Ibid, 11

${ }^{33}$ Ibid, 1

${ }^{34}$ Ibid, 1

${ }^{35}$ Nakamura, M. Changing Corporate Governance Practices in Chaina and Japan. United Kingdom: Palgrave Macmillan, (2008).

${ }^{36}$ Ibid,30
} 
directors are genuinely independent taking into consideration their mode of appointment and compensation, ${ }^{37}$. Also related to this is whether external auditors are really independent for the investors to believe in the report pertaining financial accounts of the firm. All these unsolved issue creates room for the manipulation of rules, procedures and Acts of corporate governance hence recent scandal in private companies.

\section{CONCLUSION}

As noted that most World scandals, corporations where subject to mandatory legal rules codes principles but still resulted into corporate governance failures. This calls for Uganda's private companies to avert the likely incidences of these scandals as ${ }^{38}$, state that Enron had exemplary corporate governance with independent directors and all other modern cooperate governance devises still exhibited failure. Tight regulations like Sarbanes -Oxley Act of 2002 should be thought of by the legislation.

\section{RECOMMENDATIONS}

From the literature and observation of the effectiveness of rule, procedures and Act to the performance of corporate governance in developing countries like Uganda has still a long way to go to strengthen the corporate governance systems as these economies evolves. Though the hybrid nature of corporate governance adopted by private companies seem to be effective it may be more important if stringent laws are legislated like what happen in the US that's Oxley Act 2002 and also adoption of apply and explain other than comply and explain model of implementing corporate governance.

\section{REFERENCES}

1. Amin, M. E. (2004). Foundation of Statistical Inferences for Social Science Research . Kampala: Makerere Printery.

2. Ansari, S. P. (2014). A Theoretical Framework for Corporate Governance. Indian Journal of Corporate Governance, Vol,7, N0.1.

3. Authority, C. M. (2003). The Capaital Market Corporate Governace Guidlines. Kampala.

4. Bratanovic, H. v. (2009). Analyzing Banking Risk A Framework for Assessing Corporate Governance and Risk Management. Washington. DC: World Bank.

5. Crowther, G. A. (2010). A Handbook of Corporate Governance and Social Responsibility. England: Gower Publishing Limited.

6. Eisenberg, P. (2016). Case Study Analysis of Corporate Governance and Management Control at Kendallville Bank. International Journal of Applied Economic Studies, Vol. 4, Issue 3.

7. Governmet, U. (1995). The Constitution of The Republic of Uganda. Kampala.

8. Hopt, A. M. (2013). Comperative Corperate Governance: A Functional and International Alysisi. United Kingdom: Cambridge University Press.

9. Hudson, K. K. (2002). Non-Executive Directors and the Higgs Consultation paper, 'Review of the Role and Effectiveness of Non-Executive Directors'. Journal of Financial Regulation and Compliance, Vol. 10 Issue: 4 , pp.361-371.

10. Mallin, C. (2013). Corporate Governance fourth edition. United Kingdom: Oxford University Press.

11. Marnet, O. (2008). Behaviour and Rationality in Corporate Governance. New York: Routledge.

12. Matthias Nnadi, U. E. (2017). Audit Quality, Family Business and Corporate Governance Mechanisms: The Case of Morocco. Journal of Accounting in Emerging Economies, Vol. 7 Issue: 4.

13. Nakamura, M. (2008). Changing Corporate Governance Practices in Chaina and Japan. United Kingdom: Palgrave Macmillan.

37 Ibid, 26

${ }^{38}$ Ibid, 7 
14. Okoye, N. V. (2015). Behavioural Risks in Corporate Governance: Regulatory Intervention as a Risk Management Mechanism. New York: Routledge.

15. Quéré, C. R. (2014). The Role of the State in Corporate Governance. Accounting History, Vol. 19(3) 291.

16. Quinlan, C. B. (2015). Business Research Mothods. Hampshire: Cengage.

17. Subramanian1, S. (2016). A Comparison of Corporate Governance Practices in State-owned Enterprises and Their Private Sector Peers in India. IIM Kozhikode Society \& Management Review, 5(2) 200-216.

18. Wanyama, S. (2014). Corporate Governance in Uganda: An Introduction to Concepts and Principles. Kampala: Fountain Publishers. 